\title{
Clones, genes, and reproductive autonomy: The ethics of human cloning
}

Link to publication record in Manchester Research Explorer

\section{Citation for published version (APA):}

Harris, J. (2000). Clones, genes, and reproductive autonomy: The ethics of human cloning. In Annals of the New York Academy of Sciences/Ann. New York Acad. Sci. (Vol. 913, pp. 209-217). New York Academy of Sciences.

\section{Published in:}

Annals of the New York Academy of Sciences|Ann. New York Acad. Sci.

\section{Citing this paper}

Please note that where the full-text provided on Manchester Research Explorer is the Author Accepted Manuscript or Proof version this may differ from the final Published version. If citing, it is advised that you check and use the publisher's definitive version.

\section{General rights}

Copyright and moral rights for the publications made accessible in the Research Explorer are retained by the authors and/or other copyright owners and it is a condition of accessing publications that users recognise and abide by the legal requirements associated with these rights.

\section{Takedown policy}

If you believe that this document breaches copyright please refer to the University of Manchester's Takedown Procedures [http://man.ac.uk/04Y6Bo] or contact uml.scholarlycommunications@manchester.ac.uk providing relevant details, so we can investigate your claim.

\section{OPEN ACCESS}




\title{
Clones, Genes, and Reproductive Autonomy
}

\section{The Ethics of Human Cloning}

\author{
JOHN HARRIS \\ The Center for Social Ethics and Policy, The University of Manchester, Oxford Road, \\ Manchester M13 9PL, England, U.K.
}

\section{INTRODUCTION}

The recent announcement of a birth in the press has caused a sensation probably unparalleled for two millennia and has highlighted the impact of the genetic revolution on our lives and personal choices. More importantly perhaps, it raises questions about the legitimacy of the sorts of control individuals and society purport to exercise over something which, while it must sound portentous, is nothing less than human destiny. This birth, that of "Dolly" the cloned sheep, is also illustrative of the responsibilities of science and scientists to the communities in which they live and in which they serve, and of the public anxiety that sensational scientific achievements sometimes provoke.

\section{NUCLEAR SUBSTITUTION: THE BIRTH OF DOLLY}

Dolly's birth ${ }^{1}$ was reported in Nature on February $27,1997 .{ }^{2}$ The event caused an international sensation: President Clinton of the United States called for an investigation into the ethics of such procedures and announced a moratorium on public spending on human cloning; the British Nobel Prize winner, Joseph Rotblat, described it as science out of control, creating "a means of mass destruction" 3 ; and the German newspaper Die Welt, evoking the Third Reich, commented: "The cloning of human beings would fit precisely into Adolph Hitler's worldview." 4

More sober commentators were similarly panicked into instant reaction. Dr. Hiroshi Nakajima, Director General of the World Health Organization said: "WHO considers the use of cloning for the replication of human individuals to be ethically unacceptable as it would violate some of the basic principles which govern medically assisted procreation. These include respect for the dignity of the human being and protection of the security of human genetic material." WHO followed up the line taken by Nakajima with a resolution of the Fiftieth World Health Assembly, which saw fit to affirm "that the use of cloning for the replication of human individuals is ethically unacceptable and contrary to human integrity and morality." 6 Federico Mayor of UNESCO, equally quick off the mark, commented: "Human beings must not be cloned under any circumstances. Moreover, UNESCO's International Bioethics Committee (IBC), which has been reflecting on the ethics of scientific progress, has maintained that the human genome must be preserved as [the] common heritage of humanity."7 
The European Parliament rushed through a resolution on cloning, the preamble of which asserted (Paragraph B):

[T]he cloning of human beings..., cannot under any circumstances be justified or tolerated by any society, because it is a serious violation of fundamental human rights and is contrary to the principle of equality of human beings as it permits a eugenic and racist selection of the human race, it offends against human dignity and it requires experimentation on humans...

It then went on to claim that (Clause 1)

... each individual has a right to his or her own genetic identity and that human cloning is, and must continue to be, prohibited. ${ }^{8}$

These statements are, perhaps unsurprisingly, thin on argument and rationale; they appear to have been plucked from the air to justify an instant reaction. There are vague references to "human rights" or "basic principles," with little or no attempt to explain what these principles are, or to indicate how they might apply to cloning. The WHO statement, for example, refers to the basic principles that govern human reproduction and singles out "respect for the dignity of the human being" and "protection of the security of genetic material." How, we are entitled to ask, is the security of genetic material compromised? Is it less secure when inserted with precision by scientists, or when spread around with the characteristic negligence of the average human male? ${ }^{9}$

The UNESCO approach to cloning is scarcely more coherent than that of the WHO: how does cloning affect "the preservation of the human genome as common heritage of humanity"? Cloning cannot be said to have an impact on the variability of the human genome; it merely repeats one infinitely small part of it, a part that is repeated at a natural rate of about 3.5 per thousand births. ${ }^{10}$

\section{GENETIC VARIABILITY}

So many of the fears expressed about cloning, and indeed about genetic engineering more generally, invoke the idea of the effect on the gene pool or upon genetic variability or assert the sanctity of the human genome as a common resource or heritage. It is very difficult to understand what is allegedly at stake here. The issue of genetic variation need not detain us long. The numbers of twins produced by cloning will always be so small compared to the human gene pool in totality, such that the effect on the variation of the human gene pool will be vanishingly small. We can say with confidence that the human genome and the human population were not threatened at the start of the present millennium in the year $1000 \mathrm{AD}$, and yet the world population was then perhaps $1 \%$ of what it is today. Natural species are usually said to be endangered when the population falls to about one thousand breeding individuals; by these standards fears for humankind and its genome may be said to have been somewhat exaggerated. ${ }^{11}$

The resolution of the European Parliament goes into slightly more detail; having repeated the now mandatory waft in the direction of fundamental human rights and human dignity, it actually produces an argument. It suggests that cloning violates the principal of equality, "as it permits a eugenic and racist selection of the human race." Well, so does prenatal and pre-implantation screening, not to mention egg donation, 
sperm donation, surrogacy, abortion and human preference in choice of sexual partner. The fact that a technique could be abused does not constitute an argument against the technique, unless there is no prospect of preventing the abuse or wrongful use. To ban cloning on the grounds that it might be used for racist purposes is tantamount to saying that sexual intercourse should be prohibited because it permits the possibility of rape.

The second principle appealed to by the European Parliament states that "each individual has a right to his or her own genetic identity." Leaving aside the inevitable contribution of mitochondrial DNA, ${ }^{12}$ we have seen that, as in the case of natural identical twins, genetic identity is not an essential component of personal identity, ${ }^{13}$ nor is it necessary for "individuality." Moreover, unless genetic identity is required either for personal identity, or for individuality, it is not clear why there should be a right to such a thing. But if there is, what are we to do about the rights of identical twins?

Suppose there came into being a life-threatening (or even disabling) condition that affected pregnant women and that there was an effective treatment, the only side effect of which was that it caused the embryo to divide, resulting in twins. Would the existence of the supposed right conjured up by the European Parliament mean that the therapy should be outlawed? Suppose that an effective vaccine for HIV was developed which had the effect of doubling the natural twining rate; would this be a violation of fundamental human rights? Are we to foreclose the possible benefits to be derived from human cloning on so flimsy a basis? We should recall that the natural occurrence of monozygotic (identical) twins is one in 270 pregnancies. This means that in the United Kingdom, with a population of about 58 million, more than 200 thousand such pregnancies have occurred. How are we to regard human rights violations on such a grand scale?

\section{HUMAN DIGNITY}

Typical of appeals to human dignity was that contained in the World Health Organization statement on cloning issued on March 11, 1997:

[The] WHO considers the use of cloning for the replication of human individuals to be ethically unacceptable as it would violate some of the basic principles which govern medically assisted procreation. These include respect for the dignity of the human being...

Appeals to human dignity, are of course universally attractive; they are also comprehensively vague. A first question to ask when the idea of human dignity is invoked is: whose dignity is attacked and how? If it is the duplication of a large part of the human genome that is supposed to constitute the attack on human dignity, or where the issue of "genetic identity" is invoked, we might legitimately ask whether and how the dignity of a natural twin is threatened by the existence of her sister and what follows as to the permissibility of natural monozygotic twinning? However, the notion of human dignity is often linked to Kantian ethics and it is this link I wish to examine more closely here.

A typical example, and one that attempts to provide some basis for objections to cloning based on human dignity, was Axel Kahn's invocation of this principle in his commentary on cloning in Nature. Kahn, a distinguished molecular biologist, helped 
draft the French National Ethics Committee's report on cloning. In Nature Kahn states $^{14}$ :

The creation of human clones solely for spare cell lines would, from a philosophical point of view, be in obvious contradiction to the principle expressed by Emmanuel Kant: that of human dignity. This principle demands that an individual-and I would extend this to read human life-should never be thought of as a means, but always also as an end. Creating human life for the sole purpose of preparing therapeutic material would clearly not be for the dignity of the life created.

The Kantian principle, invoked without any qualification or gloss, is seldom helpful in medical or bioscience contexts. ${ }^{15}$ As formulated by Kahn, for example, it would surely outlaw blood transfusions. The beneficiary of blood donation, neither knowing of, nor usually caring about, the anonymous donor uses the blood (and its donor) exclusively as a means to her own ends. The recipient of blood donations does not usually know of or even care about the identity of the blood donor. The donor figures in the life of the recipient of blood exclusively as a means. The blood in the bottle has after all less identity, and is less connected with the individual from which it emanated, than the chicken "nuggets" on the supermarket shelf. An abortion performed exclusively to save the life of the mother would also, presumably, be outlawed by this principle.

\section{INSTRUMENTALIZATION}

This idea of using individuals as a means to the purposes of others is sometimes termed "instrumentalization," particularly in the European context. The "Opinion of the group of advisers on the ethical implications of biotechnology to the European Commission," 16 for example, in its statement on "ethical aspects of cloning techniques," uses this idea repeatedly. For example, referring to reproductive human cloning (paragraph 2.6) it states: "Considerations of instrumentalization and eugenics render any such acts ethically unacceptable."

Applying this idea coherently or consistently is not easy! If someone wants to have children in order to continue his or her genetic line does that person act instrumentally? Where, as is standard practice in IVF, spare embryos are created, are these embryos created instrumentally?

Kahn responded in the journal Nature to these objections. ${ }^{17} \mathrm{He}$ reminds us, rightly, that Kant's famous principle states: "respect for human dignity requires that an individual is never used...exclusively as a means" and suggests that I have ignored the crucial use of the term "exclusively." I did not of course, and I am happy with Kahn's reformulation of the principle. It is not that Kant's principle does not have powerful intuitive force, but that it is so vague and so open to selective interpretation and its scope for application is consequently so limited, that its utility as one of the "fundamental principles of modern bioethical thought," as Kahn describes it, is virtually zero.

Kahn himself rightly points out that debates concerning the moral status of the human embryo are debates about whether embryos fall within the scope of Kant's or indeed any other moral principles concerning persons; so the principle itself is not illuminating in this context. Applied to the creation of individuals, which are, or will become autonomous, it has limited application. True the Kantian principle rules out 
slavery, but so do a range of other principles based on autonomy and rights. If you are interested in the ethics of creating people, then, so long as existence is in the created individual's own best interests, and the individual will have the capacity for autonomy like any other, then the motives for which the individual was created are either morally irrelevant or subordinate to other moral considerations. So that even where, for example, a child is engendered exclusively to provide "a son and heir" (as so often occurs in so many cultures), it is unclear how or whether Kant's principle applies. Either other motives are also attributed to the parent to square parental purposes with Kant, or the child's eventual autonomy, and its clear and substantial interest in or benefit from existence, take precedence over the comparatively trivial issue of parental motives. Either way the "fundamental principle of modern bioethical thought" is unhelpful.

It is therefore strange that Kahn and others invoke it with such dramatic assurance or how anyone could think that it applies to the ethics of human cloning. It comes down to this: either the ethics of human cloning turn on the creation or use of human embryos, in which case as Kahn himself says "in reality the debate is about the status of the human embryo" and Kant's principle must wait upon the outcome of that debate. Or, it is about the ethics of producing clones that will become autonomous human persons. In this latter case, as David Shapiro also comments, ${ }^{18}$ the ethics of their creation are, from a Kantian perspective, not dissimilar to other forms of assisted reproduction, or, as I have suggested, to the ethics of the conduct of parents concerned exclusively with producing an heir, or preserving their genes or, as is sometimes alleged, making themselves eligible for public housing. Debates about whether these are exclusive intentions can never be definitively resolved.

Kahn then produces a bizarre twist to the argument from autonomy. Kahn defines autonomy as "the indeterminability of the individual with respect to external human will" and identifies it as one of the components of human dignity. This is of course hopeless as a definition of autonomy: those in a persistent vegetative state (PVS), and indeed all newborns, would on such a view have to count as autonomous! However Kahn then asserts: "The birth of an infant by asexual reproduction would lead to a new category of people whose bodily form and genetic make-up would be exactly as decided by other humans. This would lead to the establishment of an entirely new type of relationship between the "created" and the "creator" which has obvious implications for human dignity. Kahn is, I'm afraid, wrong on both counts. As Robert Winston has noted: "[E]ven if straight cloning techniques were used, the mother would contribute important constituents-her mitochondrial genes, intrauterine influences and subsequent nurture." 19 These, together with the other influences, would prevent exact determination of bodily form and genetic identity. For example, differences in environment, age, and number of years between clone and cloned would all come into play.

Lenin's embalmed body lies in its mausoleum in Moscow. Presumably a cell of this body could be de-nucleated and Lenin's genome cloned. Could such a process make Lenin immortal and allow us to create someone whose bodily form and genetic makeup, not to mention his character and individuality, would be "exactly as decided by other human beings"? I hope the answer is obvious. Vladimir Ilyich Ulyanov was born on April 10, 1870 in the town of Simbirsk on the Volga. It is this person who became and who is known to most of us as V.I. Lenin. Even with this man's genome 
preserved intact we will never see Lenin again. So many of the things that made Vladimir Ilyich what he was cannot be reproduced even if his genome can. We cannot recreate pre-Revolutionary Russia. We cannot simulate Lenin's environment and education. We cannot recreate his parents to bring him up and influence his development as profoundly as they undoubtedly did. We cannot make the thought of Karl Marx seem as hopeful as it must then have done. We cannot, in short, do anything but reproduce his genome and that could never be nearly enough. It may be that "manners maketh man," but genes most certainly do not.

Autonomy, as we know from monozygotic twins, is unaffected by close similarity of bodily form and matching genome. The "indeterminability of the individual with respect to external human will" will remain unaffected by cloning. Where then are the obvious implications for human dignity?

When Kahn asks: "Is Harris announcing the emergence of a revisionist tendency in bioethical thinking?" the answer must be, rather I am pleading for the emergence of "bioethical thinking" as opposed to the empty rhetoric of invoking resonant principles with no conceivable or coherent application to the problem at hand.

Clearly the birth of Dolly and the possibility of human equivalents has left many people feeling not a little uneasy, if not positively queasy at the prospect. It is perhaps salutary to remember that there is no necessary connection between phenomena, attitudes, or actions that make us uneasy, or even those that disgust us, and those phenomena, attitudes, and actions that there are good reasons for judging unethical. Nor does it follow that those things we are confident are unethical must be prohibited by legislation or controlled by regulation. These are separate steps, which require separate arguments.

\section{PROCREATIVE AUTONOMY}

We have examined the arguments for and against permitting the cloning of human individuals. At the heart of these questions is the issue of whether or not people have rights to control their reproductive destiny and, so far as they can do so without violating the rights of others or threatening society, to choose their own procreative path. We have seen that it has been claimed that cloning violates principles of human dignity. We will conclude by briefly examining an approach that suggests that failing to permit cloning might violate principles of dignity.

The American philosopher and legal theorist, Ronald Dworkin, has outlined the arguments for a right to what he calls "procreative autonomy" and has defined this right as "a right to control their own role in procreation unless the state has a compelling reason for denying them that control." 20 Arguably, freedom to clone one's own genes might also be defended as a dimension of procreative autonomy because so many people and agencies have been attracted by the idea of the special nature of genes and have linked the procreative imperative to the genetic imperative.

The right of procreative autonomy follows from any competent interpretation of the due process clause and of the Supreme Court's past decisions applying it... . The First Amendment prohibits government from establishing any religion, and it guarantees all citizens free exercise of their own religion. The Fourteenth Amendment, which incorporates the First Amendment, imposes the same prohibition and same responsibility on states. These provisions also guarantee the right of procreative autonomy. ${ }^{21}$ 
The point is that the sorts of freedoms that freedom of religion guarantees, freedom to choose one's own way of life and live according to one's most deeply held beliefs, are also at the heart of procreative choices. And Dworkin concludes:

...that no one may be prevented from influencing the shared moral environment, through his own private choices, tastes, opinions, and example, just because these tastes or opinions disgust those who have the power to shut him up or lock him up. ${ }^{22}$

Thus it may be that we should be prepared to accept both some degree of offence and some social disadvantages as a price we should be willing to pay in order to protect freedom of choice in matters of procreation and perhaps this applies to cloning as much as to more straightforward or usual procreative preferences. ${ }^{23}$

The nub of the argument is complex and abstract but it is worth stating at some length. I cannot improve upon Dworkin's formulation of it.

The right of procreative autonomy has an important place...in Western political culture more generally. The most important feature of that culture is a belief [in] individual human dignity: that people have the moral right — and the moral responsibility — to confront the most fundamental questions about the meaning and value of their own lives for themselves, answering to their own consciences and convictions.... The principle of procreative autonomy, in a broad sense, is embedded in any genuinely democratic
culture.

The rationale that animated the principle of procreative autonomy was made the subject of a submission to the United States Court of Appeals by Ronald Dworkin and a group of other prominent philosophers. Their submission was in a case concerning voluntary euthanasia and it is interesting because it cites a number of United States Supreme Court decisions and their rationales:

Certain decisions are momentous in their impact on the character of a person's life decisions about religious faith, political and moral allegiance, marriage, procreation and death, for example. Such deeply personal decisions reflect controversial questions about how and why human life has value. In a free society, individuals must be allowed to make those decisions for themselves, out of their own faith, conscience and convictions. This Court has insisted, in a variety of contexts and circumstances, that this great freedom is among those protected by the Due Process Clause as essential to a community of "ordered liberty." Palko v. Connecticut, 302 U.S. 319, 325 (1937).

In its recent decision in Planned Parenthood v. Casey, 505 U.S. 833, 851 (1992), the Court offered a paradigmatic statement of that principle: ...matters involving the most intimate and personal choices a person may make in a lifetime, choices central to a person's dignity and autonomy are central to the liberty protected by the Fourteenth Amendment.

As the Court explained in West Virginia State Board of Education v. Barnette, 319 U.S. 624,642 (1943): If there is any fixed star in our constitutional constellation, it is that no official can prescribe what shall be orthodox in politics, nationalism, religion, or other matters of opinion or force citizens to confess by word or act their faith therein.

Interpreting the religion clauses of the First Amendment, this Court has explained that "the victory for freedom of thought recorded in our Bill of Rights recognizes that in the domain of conscience there is a moral power higher than the State." Girouard v. United States, 328 U.S. 61, 68 (1946).

And, in a number of Due Process cases, this Court has protected this conception of autonomy by carving out a sphere of personal family life that is immune from government intrusion. See e.g., Cleveland Bd. of Educ. v. LeFleur, 414 U.S. 632, 639 (1974) ("This Court has long recognized that freedom of personal choice in matters of marriage and family life is one of the liberties protected by the Due Process Clause of the Fourteenth Amendment."); Eisenstadt v. Baird, 405 U.S. 438, 453 (1973) (recognizing right "to be free from unwarranted governmental intrusion into matters so fundamentally affecting a person as the decision to bear and beget a child"); 
Skinner v. Oklahoma, 316 U.S. 535, 541 (1942) (holding unconstitutional a state statute requiring the sterilization of individuals convicted of three offenses, in large part because the state's actions unwarrantedly intruded on marriage and procreation, "one of the basic civil rights of man");

Loving v. Virginia, 388 U.S. 1, 12 (1967) (striking down the criminal prohibition of interracial marriages as an infringement of the right to marry and holding that "the freedom to marry has long been recognized as one of the vital personal rights essential to the orderly pursuit of happiness by free men"). ${ }^{25}$

These decisions recognize as constitutionally immune from state intrusion that realm in which individuals make "intimate and personal" decisions that define the very character of their lives.

In so far as decisions to reproduce in particular ways or even using particular technologies constitute decisions concerning central issues of value, then arguably the freedom to make them is guaranteed by the constitution (written or not) of any democratic society, unless the state has a compelling reason for denying them that control. To establish such a compelling reason the state (or indeed a federation or union of states, like the European Union for example) would have to show that more was at stake than the fact that a majority found the ideas disturbing or even disgusting.

As yet, in the case of human cloning, such compelling reasons have not been produced. Suggestions have been made, but have not been sustained, that human dignity may be compromised by the techniques of cloning. Dworkin's arguments suggest that human dignity and indeed democratic constitutions may be compromised by attempts to limit procreative autonomy, at least where greater values cannot be shown to be thereby threatened. This paper has argued that no remotely plausible arguments exist as to how human cloning might pose significant dangers or threats or that it may compromise important human values. It has shown that there is a prima facie case for regarding human cloning as a dimension of procreative autonomy that should not be lightly restricted.

\section{NOTES AND REFERENCES}

1. Some of the material in this paper was presented to the UNDP/WHO/World Bank Special Programme of Research, Development and Research Training in Human Reproduction Review Group Meeting, Geneva (25 April 1997) and to a hearing on cloning held by the European Parliament in Brussels (7 May 1997). I am grateful to participants at these events for many stimulating insights. I must also thank Justine Burley, Christopher Graham and Pedro Lowenstein for many constructive comments. The issues raised by cloning were discussed in a special issue of the Kennedy Institute of Ethics Journal, Vol. 4, No. 3 (September 1994) and in my Wonderwoman and Superman: The Ethics of Human Biotechnology (Oxford: Oxford University Press, 1992), especially Chapter 1 . Versions of the ideas expressed here have appeared in my "Goodbye Dolly: The Ethics of Human Cloning," The Journal of Medical Ethics, Vol. 23, No. 6, 353-361, and in my "Cloning and Human Dignity," Cambridge Quarterly of Healthcare Ethics, Vol. 7 (1998), pp. 163-167. Readers will note that this is a modified and abbreviated version of my "Clones, Genes and Human Rights," which appeared in Justine Burley (Ed.), The Genetic Revolution and Human Rights (Oxford: Oxford University Press, 1998), pp. 61-95. My participation in the meeting that gave rise to this volume was made possible by a generous grant by The British Council.

2. Wilmut et al. "Viable Offspring Derived from Fetal and Adult Mammalian Cells," Nature (27 February 1997).

3. The Guardian (26 February 1997). 
4. Reported in The Guardian (28 February 1997).

5. WHO Press Release (WHO/20 11 March 1997).

6. WHO document (WHA50.37 14 May 1997), despite the findings of a Meeting of the Scientific and Ethical Review Group (see note 1), which recommended that "the next step should be a thorough exploration and fuller discussion of the [issues]."

7. UNESCO Press Release No. 97-29.

8. The European Parliament, Resolution on Cloning, Motion dated 11 March 1997. Passed 13 March 1997.

9. Perhaps the sin of Onan was to compromise the security of his genetic material?

10. It is unlikely that "artificial" cloning would ever approach such a rate on a global scale and we could, of course, use regulative mechanisms to prevent this without banning the process entirely. I take this figure of the rate of natural twinning from Keith L Moore and T.V.N. Persaud, The Developing Human (Philadelphia: W.B. Saunders, 1993), 5th ed. The rate mentioned is 1 per 270 pregnancies.

11. Of course if all people were compulsorily sterilized and reproduced only by cloning, genetic variation would become fixed at current levels. This would halt the evolutionary process. How bad or good this would be could only be known if the course of future evolution and its effects could be accurately predicted.

12. Mitochondrial DNA individualizes the genotype even of clones to some extent.

13. Although, of course, there would be implications for criminal justice since clones could not be differentiated by so called "genetic fingerprinting" techniques

14. Axel Kahn "Clone Mammals...Clone Man," Nature, Vol. 386 (13 March 1997), p. 119.

15. See my "Is Cloning an Attack on Human Dignity," Nature, Vol. 387, 754 (19 June 1997).

16. Opinion of the Group of Advisers on the Ethical Implications of Biotechnology to the European Commission No 9 (28 May 1997). Rapporteur: Dr. Anne McClaren.

17. Axel Kahn, Nature, Vol. 388, 320 (24 July 1997)

18. Nature, Vol. 388, 511 (7 August 1997).

19. Robert Winston, British Medical Journal, Vol. 314 (1997), pp. 913-914.

20. Ronald Dworkin Life's Dominion (London: Harper \& Collins, 1993), p. 148.

21. Ronald Dworkin, Life's Dominion, p. 160.

22. Ronald Dworkin Freedom's Law (Oxford: Oxford University Press, 1996), pp. 237-238.

23. Ronald Dworkin has produced an elegant account of the way the price we should be willing to pay for freedom might or might not be traded off against the costs. See his Taking Rights Seriously (London: Duckworth, 1977), chapt. 10 and his A Matter of Principle (Cambridge, MA: Harvard University Press, 1985), chapt. 17.

24. Ronald Dworkin, Life's Dominion, pp. 166-167.

25. State of Washington et al. Petitioners, v Harold Glucksberg et al., Respondents; Dennis C. Vacco, Attorney General of New York, et al., Petitioners, v. Timothy E. Quill, et al., Respondents. Nos. 5-1858, 96-110 (10 December 1996). Brief for Ronald Dworkin, Thomas Nagel, Robert Nozick, John Rawls, Thomas Scanlon and Judith Jarvis Thomson as amici curiae in support of respondents. 